\title{
Identification and characterization of MtoA: a decaheme c-type cytochrome of the neutrophilic Fe(II)-oxidizing bacterium Sideroxydans lithotrophicus ES-1
}

\section{Juan Liu ${ }^{1}$, Zheming Wang ${ }^{1}$, Sara M. Belchik ${ }^{1}$, Marcus J. Edwards ${ }^{2}$, Chongxuan Liu ${ }^{1}$, David W. Kennedy ${ }^{1}$, Eric D. Merkley ${ }^{1}$, Mary S. Lipton ${ }^{1}$, Julea N. Butt ${ }^{2}$, David J. Richardson ${ }^{2}$, John M. Zachara', James K. Fredrickson ${ }^{1}$, Kevin M. Rosso ${ }^{1}$ and Liang Shi ${ }^{1 *}$}

${ }^{1}$ Pacific Northwest National Laboratory, Richland, WA, USA

${ }^{2}$ Centre for Molecular and Structural Biochemistry, School of Biological Sciences and School of Chemistry, University of East Anglia, Norwich Research Park, Norwich, UK

\section{Edited by:}

David Emerson, Bigelow Laboratory

for Ocean Sciences, USA

\section{Reviewed by:}

Violaine Bonnefoy, Centre National de la Recherche Scientifique, France Yongqin Jiao, Lawrence Livermore National Laboratory, USA

*Correspondence:

Liang Shi, Microbiology Group, Pacific Northwest National Laboratory, 902 Battelle Blvd., P.O. Box 999, Richland, WA 99352, USA.

e-mail: liang.shi@pnnl.gov
The Gram-negative bacterium Sideroxydans lithotrophicus ES-1 (ES-1) grows on $\mathrm{FeCO}_{3}$ or FeS at oxic-anoxic interfaces at circumneutral $\mathrm{pH}$, and the ES-1-mediated Fe(II) oxidation occurs extracellularly. However, the molecular mechanisms underlying ES-1's ability to oxidize Fe(II) remain unknown. Survey of the ES-1 genome for candidate genes for microbial extracellular Fe(II) oxidation revealed that it contained a three-gene cluster encoding homologs of Shewanella oneidensis MR-1 (MR-1) MtrA, MtrB, and CymA that are involved in extracellular Fe(III) reduction. Homologs of MtrA and MtrB were also previously shown to be involved in extracellular Fe(II) oxidation by Rhodopseudomonas palustris TIE1. To distinguish them from those found in MR-1, the identified homologs were named MtoAB and CymA $A_{E S-1}$. Cloned mtoA partially complemented an MR-1 mutant without MtrA with regards to ferrihydrite reduction. Characterization of purified MtoA showed that it was a decaheme $c$-type cytochrome and oxidized soluble Fe(II). Oxidation of Fe(II) by MtoA was $\mathrm{pH}$ - and Fe(II)-complexing ligand-dependent. Under conditions tested, MtoA oxidized Fe(II) from $\mathrm{pH} 7$ to $\mathrm{pH} 9$ with the optimal rate at $\mathrm{pH}$ 9. MtoA oxidized Fe(II) complexed with different ligands at different rates. The reaction rates followed the order $\mathrm{Fe}(\mathrm{II}) \mathrm{Cl}_{2}>\mathrm{Fe}(\mathrm{II})-$ citrate $>\mathrm{Fe}(\mathrm{II})-\mathrm{NTA}>\mathrm{Fe}(\mathrm{II})-\mathrm{EDTA}$ with the second-order rate constants ranging from $6.3 \times 10^{-3} \mu \mathrm{M}^{-1} \mathrm{~s}^{-1}$ for oxidation of Fe(II)Cl 2 to $1.0 \times 10^{-3} \mu \mathrm{M}^{-1} \mathrm{~s}^{-1}$ for oxidation of Fe(II)-EDTA. Thermodynamic modeling showed that redox reaction rates for the different $\mathrm{Fe}$ (II)-complexes correlated with their respective estimated reaction-free energies. Collectively, these results demonstrate that $\mathrm{MtoA}$ is a functional Fe(II)-oxidizing protein that, by working in concert with $\mathrm{MtoB}$ and $\mathrm{CymA}_{\mathrm{ES}-1}$, may oxidize Fe(II) at the bacterial surface and transfer released electrons across the bacterial cell envelope to the quinone pool in the inner membrane during extracellular Fe(II) oxidation by ES-1.

Keywords: Sideroxydans lithotrophicus ES-1, extracellular Fe(II) oxidation, decaheme c-type cytochrome MtoA, pH-dependent, ligand complexation

\section{INTRODUCTION}

The contribution of $\mathrm{Fe}(\mathrm{II})$-oxidizing bacteria (FeOB) to iron cycling in freshwater, groundwater, and marine environments, as well as in most soils and sediments, has been well recognized (Emerson et al., 2010). A variety of neutrophilic and acidophilic $\mathrm{Fe}$ (II)-oxidizing microorganisms have the ability to derive energy for growth from the oxidation of dissolved or structural $\mathrm{Fe}(\mathrm{II})$ under either oxic or anoxic conditions. Unlike aerobic acidophilic or anaerobic neutrophilic $\mathrm{FeOB}$, the geologic importance of aerobic neutrophilic $\mathrm{FeOB}$ has long been neglected because of the rapid auto-oxidation of $\mathrm{Fe}$ (II) by $\mathrm{O}_{2}$ at circumneutral $\mathrm{pH}$. However, recent studies indicate that aerobic neutrophilic $\mathrm{FeOB}$ would play a key role in microoxic niches with low levels of $\mathrm{O}_{2}$ concentration, where microbial $\mathrm{Fe}(\mathrm{II})$-oxidation can compete with the chemical oxidation of Fe(II). For example, the Gram-negative bacterium Sideroxydans lithotrophicus ES-1 (ES-1), originally isolated from the ground water with $\mathrm{Fe}(\mathrm{II})$ at neutral $\mathrm{pH}$ in $\mathrm{MI}$, USA, grows on $\mathrm{FeCO}_{3}$ or $\mathrm{FeS}$ at oxic-anoxic interfaces (Emerson and Moyer, 1997; Emerson et al., 2007). ES-1 does not grow on $\mathrm{Mn}$ (II) oxides, sulfide, or organic carbon sources, such as acetate, pyruvate, and glucose, and does not reduce $\mathrm{Fe}(\mathrm{III})$ oxides. $\mathrm{Fe}(\mathrm{III})$ (oxy)(hydr)oxide precipitates are closely associated with the ES-1 cells, but do not form sheath- or stalk-like structures (Emerson and Moyer, 1997). Recently, the ES-1 genome was sequenced (http://www.ncbi.nlm.nih.gov/sutils/genom_table.cgi). However, the molecular mechanism by which ES-1 oxidizes Fe(II) remains unknown.

Because $\mathrm{Fe}(\mathrm{III})$ oxides produced from biotic $\mathrm{Fe}(\mathrm{II})$-oxidation are usually sparingly soluble at circumneutral $\mathrm{pH}$ and in the absence of complexing ligands, bacteria oxidize $\mathrm{Fe}(\mathrm{II})$ 
extracellularly presumably to avoid accumulation of $\mathrm{Fe}$ (III) oxides inside their cells. To overcome the physical separation between the bacterial inner membrane where microbial oxidases are located and bacterial cell surface, FeOB have evolved different electron transfer pathways that link the inner membrane to the cell surface. The pathways identified to date include Cyc-2/Rus/Cyc- 1 of Acidithiobacillus ferrooxidans, PioABC of Rhodopseudomonas palustris TIE-1 and FoxEYZ of Rhodobacter strain SW2 (AppiaAyme et al., 1999; Yarzabal et al., 2002; Croal et al., 2007; Jiao and Newman, 2007; Castelle et al., 2008). Although these systems are phylogenetically unrelated, they all have at least one $c$-type cytochrome ( $c$-Cyt) as a key electron transfer protein. These $c$-Cyts work in concert with other proteins, often in the form of proteinprotein complexes that can span the entire microbial cell envelope to facilitate electron conductance between the inner membrane and $\mathrm{Fe}(\mathrm{II})$ external to the bacterial cell.

Notably, PioAB of R. palustris TIE-1 are homologs of MtrAB of the $\mathrm{Fe}$ (III)-reducing bacterium Shewanella oneidensis MR-1 (MR-1; Jiao and Newman, 2007). In MR-1, MtrA is a decaheme $c$-Cyt, while MtrB is a trans-outer membrane (OM), porin-like protein. They form a tight protein complex that transfers electrons across the OM to MtrC and OmcA, two OM decaheme $c$-Cyts that are localized on bacterial outermost surface (Ross et al., 2007; Shi et al., 2008; Hartshorne et al., 2009; Lower et al., 2009; Reardon et al., 2010). MtrABC and OmcA are key components of the MR-1 extracellular electron transfer pathway, which also includes a tetraheme $c$-Cyt CymA in the inner membrane. Together, they facilitate electron transfer from the quinone/quinol pool in the inner membrane across the periplasm, through the OM, to the surface of Fe(III) oxides (Richardson, 2000; Shi et al., 2007, 2009; Fredrickson et al., 2008). In addition to mediating electron transfer to and from $\mathrm{Fe}, \mathrm{MtrAB}$ homologs are also involved in extracellular reduction of dimethylsulfoxide by MR-1 and are hypothesized to be the prototype of a model system for electron transfer across the bacterial OM (Gralnick et al., 2006; Hartshorne et al., 2009).

To investigate the molecular mechanism used by ES-1 for oxidizing $\mathrm{Fe}(\mathrm{II})$, we searched the ES-1 genome for the homologs of Cyc-2/Rus/Cyc-1 of A. ferrooxidans, FoxEYZ of Rhodobacter strain SW2 and PioAB/MtrAB. This search identified a three-gene cluster that encoded MtrA, MtrB, and CymA homologs. To distinguish them from those found in $\mathrm{Fe}$ (III)-reducing bacteria, we named the identified homologs MtoAB and CymA $\mathrm{ES}_{-1}$. Cloned $m$ toA partially complemented an MR-1 mutant without MtrA in ferrihydrite (FH) reduction. Recombinant MtoA was purified following overexpression in MR-1 cells and characterized systematically. Purified MtoA was found to be a decaheme $c$-Cyt and able to oxidize soluble $\mathrm{Fe}$ (II) in vitro. Collectively, these results suggest that MtoA is a $\mathrm{Fe}(\mathrm{II})$-oxidizing protein that works in concert with MtoB and $\mathrm{CymA}_{\mathrm{ES}-1}$ to mediate electron transfer reactions from the cell surface to the inner membrane during extracellular $\mathrm{Fe}(\mathrm{II})$ oxidation by ES-1.

\section{MATERIALS AND METHODS STANDARD PROCEDURES}

Protein concentrations were measured with a bicinchoninic acid (BCA) protein assay kit from Pierce (Rockford, IL, USA). Sodium dodecyl sulfate-polyacrylamide gel electrophoresis (SDS-PAGE) and Western blot analysis were conducted according to the instructions from Invitrogen (Carlsbad, CA, USA). To visualize proteins directly, gels were stained with GelCode blue stain from Pierce. Heme staining was carried out according the protocol described by Thomas et al. (1976). RGS-His antibody was used for detecting the recombinant protein tagged with RGS-His epitope by Western blot analysis (QIAGEN, Valencia, CA, USA). Kanamycin was used at $25 \mu \mathrm{g} / \mathrm{ml}$.

\section{GENE IDENTIFICATION AND CLONING}

The approach used to identify MtoAB from the ES-1 genome was similar to those described previously (Shi et al., 1998; Shi and Zhang, 2004). MR-1 MtrAB and PioAB of R. palustris TIE1 were used as templates to search for open reading frames (ORFs) whose predicted peptide products displayed similarity to the MtrAB/PioAB by BLAST $(E<0.01)$. Following their identification, the polypeptide sequences of MtoA, MtoB, or CymA $\mathrm{ES}_{\mathrm{ES}}$ and MtrA homologs, MtrB homologs, or CymA homologs of 19 sequenced Shewanella strains described by Fredrickson et al. (2008) and PioA or PioB were used to construct phylogenetic trees with the neighbor-joining-based ALGNX program of Vector NTI (Invitrogen). Likewise, the ES-1 genome was also searched for the homologs of Cyc-2/Rus/Cyc-1 of A. ferrooxidans and FoxEYZ of Rhodobacter strain SW2. The ORF for the identified MtrA homolog was synthesized and then cloned into a protein expression vector pJexpress 401 to create pLS279 by DNA 2.0 (Menlo Park, CA, USA). pLS279 was introduced into MR-1 $\Delta m t r B-m t r D$ (locus tags SO_1776-SO_1782) or $\Delta m t r A$ (SO_1777) mutant by electroporation to create LS587 and LS597, respectively (Shi et al., 2005; Hartshorne et al., 2009; Clarke et al., 2011). $\Delta m t r A$ mutant was also transformed with pJexpress 401 to create LS620.

\section{FERRIHYDRITE REDUCTION}

For ferrihydrite (FH) reduction, MR-1, LS597, and LS620 were grown in PIPES-buffered M1 medium with $20 \mathrm{mM}$ sodium lactate aerobically at $30^{\circ} \mathrm{C}$ for $16 \mathrm{~h}$ with agitation $(150 \mathrm{rpm})$ and harvested by centrifugation $(5000 \times g, 5 \mathrm{~min})$. Harvested cells were washed once with the same medium, purged with $\mathrm{N}_{2}$, and transferred to Balch tubes at final concentration of $1 \times 10^{8}$ cells $/ \mathrm{ml}$. $\mathrm{FH}$ was added at final concentration of $10 \mathrm{mM}$. The tubes were incubated horizontally at $30^{\circ} \mathrm{C}$ with shaking $(25 \mathrm{rpm}$; Shi et al., 2011). At predetermined time points, $0.5 \mathrm{~N} \mathrm{HCl}$ extractable $\mathrm{Fe}(\mathrm{II})$ was determined by the ferrozine assay (Stookey, 1970).

\section{PROTEIN PURIFICATION}

MtoA was purified from a mutant without major MR-1 $c$-Cyts, such as MtrA, MtrC, and OmcA. Compared to that in wt, yields of purified $c$-Cyts from this mutant were often two to three times higher. LS587 was grown aerobically in Tryptic Broth at $30^{\circ} \mathrm{C}$ with agitation $(150 \mathrm{rpm})$ until the culture reached an optical density at $600 \mathrm{~nm}$ of 0.6 . Isopropyl $\beta$-D-1-thiogalactopyranoside (IPTG) was added to a final concentration of $1 \mathrm{mM}$. The LS587 cells were grown for another $17 \mathrm{~h}$ and then harvested by centrifugation at $6000 \times g$ for $15 \mathrm{~min}$. The harvested cells were washed once with buffer A (20 mM HEPES, pH 7.8, $150 \mathrm{mM} \mathrm{NaCl})$ and stored at $-20^{\circ} \mathrm{C}$. Frozen cell pellets were resuspended in buffer 
B [buffer A + protease inhibitor (Roche Diagnostic, Indianapolis, IN, USA)] in a ratio of $5 \mathrm{ml} / \mathrm{g}$ wet weight cells. The cells were lysed by passage through a French press three times at $8000 \mathrm{lbf} / \mathrm{in}^{2}$. The unbroken cells and debris were removed by centrifugation at $15,000 \times g$ for $30 \mathrm{~min}$. The supernatant was transferred to ultracentrifugation tubes and further centrifuged at $150,000 \times g$ for $1 \mathrm{~h}$. The supernatant was loaded onto a $\mathrm{Ni}^{2+}$ nitrilotriacetic acid (NTA) agarose column pre-equilibrated with buffer B. The column was washed with following buffers in sequential order: buffer $\mathrm{B}$, buffer $\mathrm{C}$ [buffer $\mathrm{B}+10 \%(\mathrm{v} / \mathrm{v})$ glycerol], and buffer $\mathrm{D}$ (buffer $\mathrm{C}+40 \mathrm{mM}$ imidazole). MtoA was eluted with buffer E (buffer C $+250 \mathrm{mM}$ imidazole; Shi et al., 2005). The fractions containing MtoA were pooled and concentrated. The concentrated MtoA was loaded on a HiLoad 16/60 column of Superdex 200 and eluted with buffer B by means of an ÄKTA explorer fast protein liquid chromatography system (GE Healthcare, Piscataway, NJ, USA). The MtoA-containing fractions were pooled, concentrated, changed to buffer $\mathrm{C}$, aliquoted, and stored at $-20^{\circ} \mathrm{C}$. All protein purification steps were performed at $4^{\circ} \mathrm{C}$.

\section{MALDI-TOF MASS SPECTROMETRY}

MALDI-TOF mass spectra were acquired using a Bruker UltraFlextreme (Billerica, MA, USA) mass spectrometer operated in linear mode. The instrument was calibrated with Protein Standard II (Bruker). MtoA in the final dialysis buffer was either desalted with a C4 OMIX pipette tip (Varian, Palo Alto, CA, USA) before spotting on the MALDI target, or spotted directly. Similar results were obtained with either method. The matrix solution was $\alpha$-cyano-4-hydroxycinnamic acid in methanol. Laser power and number of lasers shots were adjusted and scans were averaged until the desired signal-to-noise ratio was obtained. Data from four experiments on three different preparations of MtoA were averaged.

\section{LIOUID CHROMATOGRAPHY-MS}

Approximately $60 \mu \mathrm{g}$ of MtoA in a volume of $200 \mu \mathrm{l}$ was denatured by adding $\sim 96 \mathrm{mg}$ of solid urea and incubating at room temperature for $1 \mathrm{~h}$. The sample was diluted 12-fold with $100 \mathrm{mM}$ ammonium bicarbonate buffer $(\mathrm{pH} 8)$ and then digested with sequencing-grade modified trypsin (Promega, Madison, WI, USA) overnight at $37^{\circ} \mathrm{C}$ at a protein-to-enzyme ratio of 20:1.The digest was desalted by solid phase extraction with a Supelco Discovery C18 cartridge. The desalted sample was then analyzed by LCtandem mass spectrometry (MS/MS) on a custom-built LC system coupled to an LTQ Orbitrap mass spectrometer (Thermo Fisher Scientific, San Jose, CA, USA) as previously described (Livesay et al., 2007). The resulting MS/MS data were searched using TurboSequest v27.12 (Eng et al., 1994), with parent mass tolerance, $50 \mathrm{ppm}$; fragment mass tolerance, $0.5 \mathrm{Da}$; partially tryptic enzyme rules; a dynamic modification on cysteine $(\mathrm{C})$ residues of 615.1694 (Yang et al., 2005), corresponding to the mass of a heme $\mathrm{C}$ group containing ${ }^{56} \mathrm{Fe}$ and accounting for the charge on the heme iron. Because heme $\mathrm{C}$ peptides are known to be difficult to identify from database searches, we manually annotated tandem mass spectra of heme $\mathrm{C}$ peptides assigned to each observed heme motif.

\section{CYCLIC VOLTAMMETRY}

Cyclic voltammetry (CV) was performed inside a Faraday cage housed in a $\mathrm{N}_{2}$-filled chamber (atmospheric $\mathrm{O}_{2}<2 \mathrm{ppm}$ ). The glass electrochemical cell contained three electrodes: a $\mathrm{Ag} / \mathrm{AgCl}$ (saturated $\mathrm{KCl}$ ) reference electrode, a basal plane pyrolytic graphite working electrode and a $\mathrm{Pt}$ wire counter electrode. The sample chamber was maintained at $4^{\circ} \mathrm{C}$. Immediately prior to each experiment the working electrode surface was lightly abraded with "Wet and Dry Abrasive Paper" of fine grade (English Abrasives and Chemicals, Stafford, UK) and polished with an aqueous $0.3-\mu \mathrm{m} \mathrm{Al}{ }_{2} \mathrm{O}_{3}$ slurry. After sonication, the electrode was rinsed, dried with a tissue and a few microliters of ice-cold solution containing $100 \mu \mathrm{M}$ MtoA in $20 \mathrm{mM}$ HEPES pH $7.6+100 \mathrm{mM}$ $\mathrm{NaCl}+10 \%(\mathrm{v} / \mathrm{v})$ glycerol were placed on the electrode. After 30 $60 \mathrm{~s}$, excess solution was removed from the electrode, which was then immersed in the desired buffer-electrolyte: $25 \mathrm{mM} \mathrm{HEPES} \mathrm{pH}$ 7.1 with $100 \mathrm{mM} \mathrm{NaCl}$, or $20 \mathrm{mM}$ Tris $\mathrm{pH}$ 7.8-9.2 with $100 \mathrm{mM}$ $\mathrm{NaCl}$. Baseline subtraction was carried out as previously described (Hartshorne et al., 2009). Midpoint potentials $\left(E_{\mathrm{m}}\right)$ were determined by fitting oxidative and reductive scans to the sum of the theoretical response for 10 centers behaving as isolated $n=1$ sites (Clarke et al., 2011). Potentials are quoted with respect to the standard hydrogen electrode (SHE) following addition of $+0.197 \mathrm{~V}$ to the measured values.

\section{SPECTROSCOPIC AND STOPPED-FLOW KINETIC MEASUREMENT}

All spectroscopic and kinetic measurements were conducted in an anoxic chamber filled with $\mathrm{N}_{2}$ from a liquid $\mathrm{N}_{2}$ boil-off supply $\left(<1\right.$ ppm $\mathrm{O}_{2}$; Innovative Technologies, Port Washington, NY, USA). MtoA stock solution containing $4 \mu \mathrm{M}$ protein, $150 \mathrm{mM}$ $\mathrm{NaCl}$, and $20 \mathrm{mM}$ HEPES buffer $(\mathrm{pH}=7.6)$ was purged with dry $\mathrm{N}_{2}$ gas for more than $1 \mathrm{~h}$, then stored at $4^{\circ} \mathrm{C}$ in serum bottles capped with thick rubber stoppers and crimp sealed. All chemicals, plastic syringes, tubes, vials, and pipette tips were deoxygenated for at least $24 \mathrm{~h}$ inside the anoxic chamber prior to use. The UV-visible absorption spectra were collected using Agilent 8452 Diode Array Spectrophotometer (Santa Clara, CA, USA). Purified MtoA was in the oxidized form. To record the spectrum of fully reduced MtoA, $10 \mathrm{mM}$ sodium dithionite solution was gradually added to $0.5 \mathrm{ml}$ of protein stock solution until no changes in the UV-visible spectra were observed. In $\mathrm{pH}$-dependent $\mathrm{Fe}$ (II) oxidation experiments, MtoA stock solution was diluted to $0.4 \mu \mathrm{M}$ in Tris buffer $(20 \mathrm{mM}$ buffer with $150 \mathrm{mM} \mathrm{NaCl}$ ) at the desired $\mathrm{pH}$ value. A small volume of $\mathrm{FeCl}_{2}$ stock solution $(15 \mathrm{mM})$ was spiked into the diluted protein solution. Absorption spectra of the resulting solution mixture were observed at $\sim 5 \mathrm{~min}$ after the spiking, allowing the reactions to reach equilibrium.

Electron transfer in the $\mathrm{Fe}$ (II) oxidation by MtoA was measured using the reaction between $39.4 \mu \mathrm{M}$ of $\mathrm{FeCl}_{2}$ and $4 \mu \mathrm{M}$ of purified MtoA solution at $\mathrm{pH}$. The amount of reduced MtoA after reaction was measured using the absorbance at the 552-nm band in the absorption spectrum. The Fe(II) concentration in the solution was measured by ferrozine assay. To minimize the spectral interference of MtoA, the solution was filtered by a $30-\mathrm{kDa}$ centrifuge filter (Amicon Ultra-0.5, Millipore, Billerica, MA, USA) at 13,000 $\times g$ for $12 \mathrm{~min}$, and then $0.4 \mathrm{ml}$ of the filtrate into $1.6 \mathrm{ml}$ ferrozine (1000 mg/l, pH 7) was added. A control experiment was conducted 
without adding MtoA solution, and the Fe(II) concentration after the same filtration process did not change substantially.

Ligand effects on oxidation of Fe(II)-complexes by MtoA were investigated using a stopped-flow system with a BioLogic MOS 250 spectrometer (Knoxville, TN, USA). The method was described in detail by Wang et al. (2008). Briefly, known volumes of MtoA and $\mathrm{Fe}$ (II)-complex solutions were rapidly mixed, and then the absorbance at $552 \mathrm{~nm}$ was tracked as a function of time. The concentration of oxidized MtoA at time $t\left(C_{t}\right)$ can be calculated from the measured absorbance $\left(A_{t}\right)$ using the following equation (Wang et al., 2008) after baseline correction:

$C_{t}=\frac{A_{t}-C_{0} \varepsilon_{\mathrm{ox}}}{\varepsilon_{\mathrm{ox}}-\varepsilon_{\mathrm{red}}}$

where $C_{0}$ is the initial concentration of oxidized MtoA, $\varepsilon_{\mathrm{ox}}$, and $\varepsilon_{\text {red }}$ are the molar absorption coefficients of the oxidized and reduced MtoA, respectively. All stopped-flow kinetic experiments were conducted in Tris buffer $(\mathrm{pH} 8)$ containing $0.4 \mu \mathrm{M}$ protein and $200 \mu \mathrm{M} \mathrm{Fe}$ (II) complexes. The ferrous iron-to-ligand ratio in Fe-citrate, Fe-NTA, and Fe-EDTA stock solutions was 1:10.

\section{ANALYSIS OF KINETIC DATA}

The overall reaction between oxidized MtoA (ox-MtoA) and $\mathrm{Fe}(\mathrm{II})$-complexes can be expressed as:

$\mathrm{Fe}(\mathrm{II})-$ ligand $+o x-\mathrm{Mto} A \rightarrow \mathrm{Fe}(\mathrm{III})-$ ligand + re-MtoA

The rate of this reaction can then be expressed as follows:

$$
\frac{d C}{d t}=-k C A(1-Q / K)
$$

where $k$ is the rate constant, $A$ and $C$ are the $\mathrm{Fe}(\mathrm{II})$ and oxidized MtoA concentrations, respectively. $Q$ is the ion activity product of the redox reaction, and $K$ is the equilibrium constant. The concentration of oxidized MtoA $(C)$ was calculated from the measured absorbance in the stopped-flow system and plotted against time. The residual $\mathrm{Fe}$ (II) concentration was calculated from the electron balance between the reacted $\mathrm{Fe}$ (II) and reduced MtoA. The calculated MtoA and $\mathrm{Fe}$ (II) concentrations as a function of time were then used to estimate rate parameters in Eq. 3. The secondorder rate constant $(k)$ and the equilibrium constant $(K)$ were determined by the slope and the ending point of the fitted line, respectively.

\section{RESULTS}

\section{IDENTIFICATION OF MtoAB AND CymA}

Search of the ES-1 genome did not reveal any homologs for Cyc-2/Rus/Cyc-1 of $A$. ferrooxidans or FoxEYZ of Rhodobacter strain SW2, but identified a gene cluster that encoded an MtrA/PioA homolog (Slit_2497) and an MtrB/PioB homolog (Slit_2496). Analysis of the genes adjacent to the mtrAB homologs also identified a cymA homolog (Slit_2495) that was next to an $m t r B$ homolog. To distinguish them from those found in MR-1 and PioAB of $R$. palustris TIE-1, we named these genes and their encoding proteins $m t o A B-c y m A$ and MtoAB/CymA $A_{E S-1}$, respectively (Figure 1). No pioC homolog was found in the

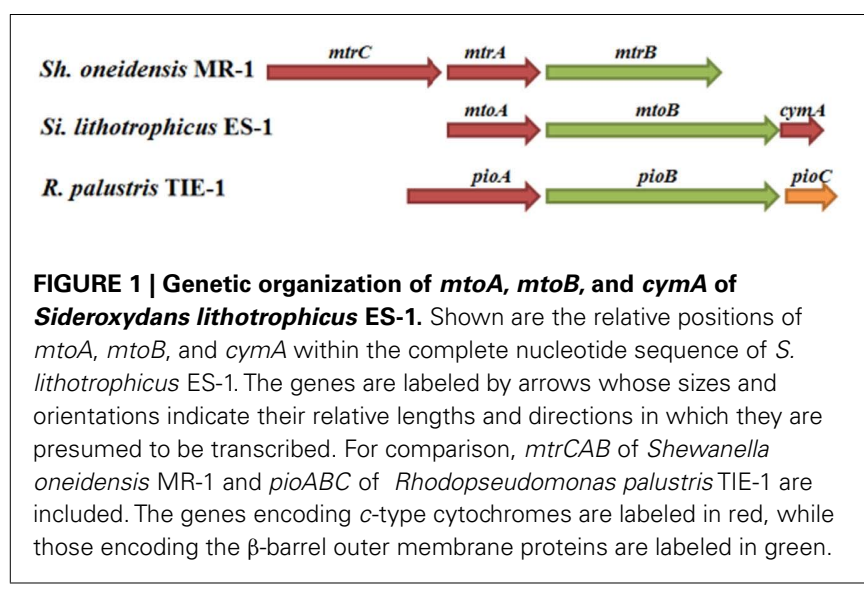

ES-1 genome. The deduced MtoA polypeptide contains 317 amino acids with calculated molecular mass of 33556.2 Da. Ten $\mathrm{CXXCH}$ motifs (i.e., putative heme-binding sites) were found within the MtoA polypeptide, suggesting that matured MtoA contains up to 10 heme co-factors. In addition to the 10 histidine residues of the $\mathrm{CX}_{2} \mathrm{CH}$ motifs, the MtoA polypeptide contained 14 more histidine residues, most of which were probably used as the distal ligands for the heme Fe. Phylogenetic analysis of the deduced amino acid sequence of MtoA with the MtrA homologs of 19 sequenced Shewanella strains (Fredrickson et al., 2008) and PioA of R. palustris TIE-1 demonstrated that MtoA was 39\% identical to PioA and $42-44 \%$ identical to the MtrA sequences analyzed. Furthermore, similar to Shewanella MtrA, MtoA lacked the N-terminal extension ( 200 amino acids) that was found in PioA polypeptides (Jiao and Newman, 2007). These results show that MtoA is almost equally related to PioA used for $\mathrm{Fe}$ (II) oxidation and MtrA for $\mathrm{Fe}$ (III) reduction, and the $\mathrm{N}$-terminal extension of PioA is probably used for specific interaction with PioBC, but not directly for $\mathrm{Fe}(\mathrm{II})$ oxidation.

Likewise, MtoB was 17\% identical to PioB and 19-21\% identical to the MtrB sequences analyzed, while CymA $\mathrm{ES}_{-1}$ was $56 \%$ identical to CymA of S. baltica OS223, 34\% to MR-1 CymA and $32-36 \%$ identical to the other CymA sequences included in the alignment. Like PioB, MtoB is $\sim 110$ amino acids longer than the MtrBs of Shewanella. Given that in MR-1, MtrAB, and CymA are the key components of the electron transfer pathway used for extracellular reduction of $\mathrm{Fe}$ (III) (Richardson, 2000; Shi et al., 2007, 2009), identification of an $m t o A B-$ cymA cluster suggests that MtoAB and CymA $\mathrm{ES}_{-1}$ may form a pathway for transferring electrons from the bacterial surface to the inner membrane during extracellular $\mathrm{Fe}$ (II) oxidation by ES-1.

\section{COMPLEMENTATION OF MR-1 mtrA DELETION MUTANT IN FERRIHYDRITE (FH) REDUCTION BY MtOA}

MtoA is a homolog of MR-1 MtrA that plays a critical role in $\mathrm{FH}$ reduction because deletion of $m$ trA impaired MR-1's ability to reduce FH (Hartshorne et al., 2009). To determine whether MtoA can facilitate trans-membrane electron transfer, pLS279 with $m t o A$ was introduced into an MR-1 $\triangle m t r A$ mutant and 
tested for FH reduction. The same mutant was also transformed with an empty vector, and the resulting strain was used as a negative control. Under the conditions tested, the MR-1 wt began to reduce $\mathrm{FH}$ within $24 \mathrm{~h}$, while no $\mathrm{FH}$ reduction was detected in the reactions mediated by $\triangle$ mtrA mutants with either empty vector or $m t o A$ at $48 \mathrm{~h}$. After $120 \mathrm{~h}, \mathrm{FH}$ reduction was detected in the reactions mediated by $\Delta$ mtrA mutant with either empty vector or $m t o A$, but no major difference was found between them. After $240 \mathrm{~h}$, wt produced $3.82 \pm 0.14 \mathrm{mM} \mathrm{Fe}(\mathrm{II})(n=3)$, while mutants with empty vector or MtoA produced $1.56 \pm 0.3$ and $3.26 \pm 0.42 \mathrm{mM} \mathrm{Fe}(\mathrm{II})(n=3)$, respectively, which were 40 and $85 \%$ of that produced by wt (Figure 2). Thus, recombinant MtoA partially complements $\triangle m t r A$ mutant in $\mathrm{FH}$ reduction, demonstrating that it can be inserted into MtrB and transfer electron across the outer membrane to MtrC during $\mathrm{FH}$ reduction. Because deletion of $m t r A$ up-regulates $m t r D$, an $m t r A$ homolog (Coursolle and Gralnick, 2010), the up-regulated MtrD may contribute to the $\mathrm{FH}$ reduction observed in the mutant with empty vector.

\section{PURIFICATION OF RECOMBINANT MtoA}

Following cell lysis and ultracentrifugation, recombinant MtoA was isolated from the soluble fraction by immobilized metal ion affinity chromatography followed by gel-filtration chromatography. The purified MtoA migrated as two bands on SDS-PAGE with apparent masses of $\sim 43$ and $86 \mathrm{kDa}$, respectively. Heme staining and Western blot analyses of the same sample showed that both bands were the heme-containing MtoA, indicating that band with $\sim 86 \mathrm{kDa}$ contained MtoA dimers (Figure 3). Measurement of purified MtoA with MALDI-TOF MS revealed that its molecular mass was $42,746 \pm 114 \mathrm{Da}(n=3)$, which was very close to $42,639 \mathrm{Da}$, the calculated molecular mass for recombinant MtoA matured with 10 heme groups. In addition, liquid

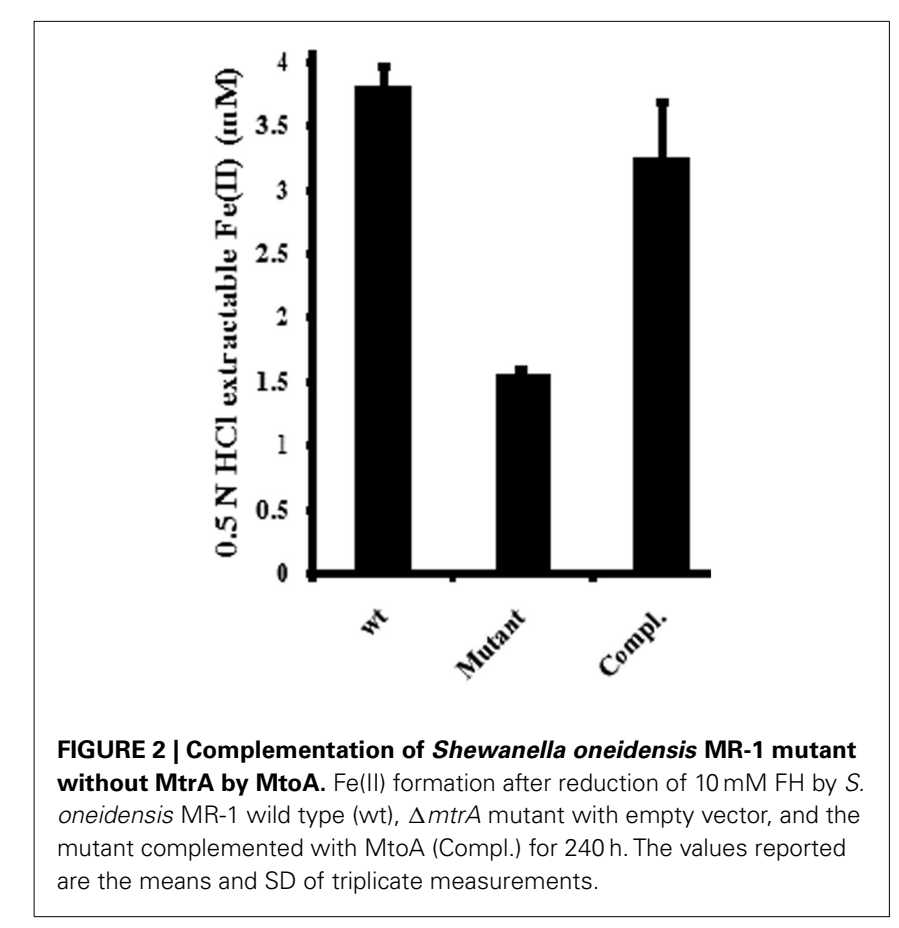

chromatography-mass spectrometry (LC-MS)/MS experiments following tryptic digest demonstrated heme modification at 8 out of $10 \mathrm{CXXCH}$ heme-binding motifs in MtoA (all but motifs 9 and 10). Presumably, peptides from motifs 9 and 10 are not observed because of a lack of trypsin cleavage sites in their vicinity. Both motifs 9 and 10 would be in the same 56-residue, 6891-Da tryptic peptide, too large to be readily analyzed by LC-MS (data not shown). All these results clearly demonstrate that purified MtoA is a decaheme $c$-Cyt.

\section{CYCLIC VOLTAMMETRY OF PURIFIED MtoA}

Cyclic voltammetry of basal plane graphite electrodes exposed to solutions of MtoA displayed clear peaks describing oxidative and reductive transformations that were not seen in the absence of MtoA (Figure 4). The oxidative and reductive peak areas were within error of each other consistent with reversible redox transformation of the adsorbed protein, and typically corresponded to $3 \times 10^{-12}$ pmol of electroactive MtoA per square centimeter assuming all 10 hemes are redox active. This electroactive population is consistent with monolayer coverage of the electrode by MtoA, and peak currents were found to be directly proportional to the scan rate confirming that the response did indeed arise from an adsorbed protein film. As shown in Figure 4, MtoA is redox active over a more positive window of potential than MR-1 MtrA at $\mathrm{pH} 7.1$, suggesting that MtoA is better poised to oxidize $\mathrm{Fe}(\mathrm{II})$ than MR-1 MtrA.

The redox properties of MtoA were measured by $\mathrm{CV}$ at $\mathrm{pH}$ $7.1,7.8,8.2$, and 9.2. For each $\mathrm{pH}$ the protein was redox active

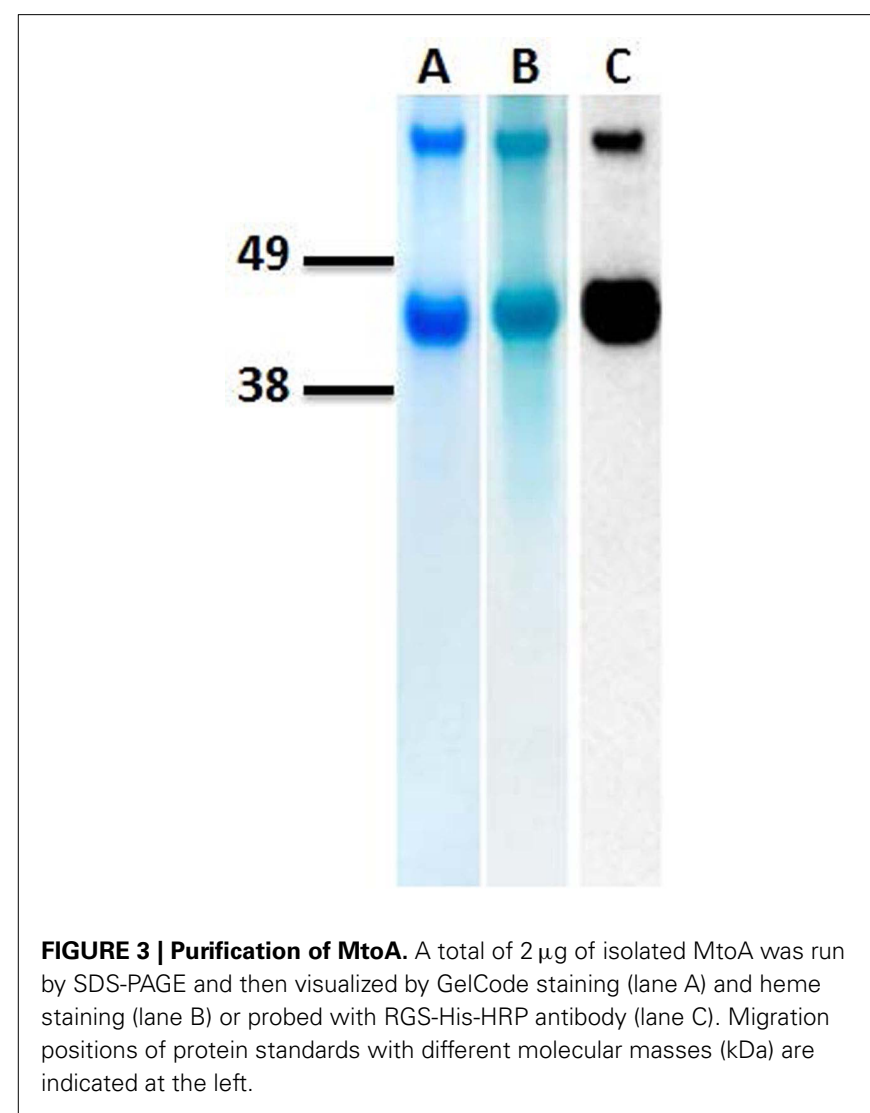




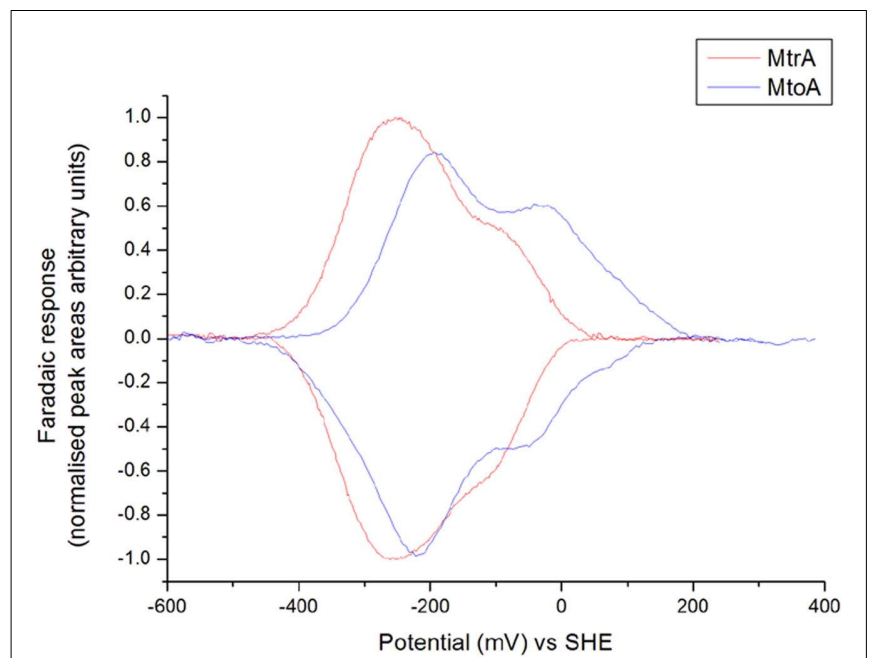

FIGURE 4 | Cyclic voltammograms of MtoA of Sideroxydans lithotrophicus ES-1 and MtrA of Shewanella oneidensis MR-1 adsorbed on graphite electrodes. Scan rate $=50 \mathrm{mV} / \mathrm{s}$, buffer-electrolyte $=25 \mathrm{mM}$ HEPES pH 7.1 with $100 \mathrm{mM} \mathrm{NaCl}, T=277 \mathrm{~K}$.

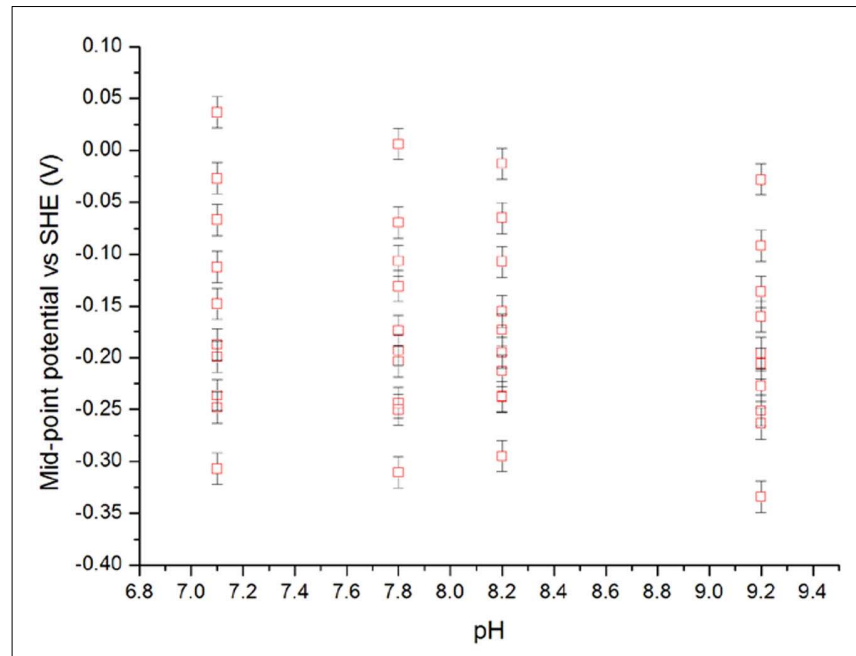

FIGURE 5 | Average $E_{\mathrm{m}}$ values determined from cyclic voltammetry of MtoA at the indicated $\mathrm{pH}$.

between $\sim+100$ and $-400 \mathrm{mV}$ (vs. SHE) with the heme $E_{\mathrm{m}}$ values clustering to define a low potential peak and a higher potential shoulder. The major impact of increased $\mathrm{pH}$ was to produce a greater proportion of hemes with lower $E_{\mathrm{m}}$. A smaller effect was a shift of the higher potential end of redox active window to more negative values. These effects were quantified by assuming that the oxidative and reductive peaks arose from the sum of contributions from 10 independent centers displaying reversible, $n=1$ electron transfer. This assumption yielded a good fit to the data and averaging the $E_{\mathrm{m}}$ values from oxidative and reductive peaks yielded 10 apparent $E_{\mathrm{m}}$ values for each $\mathrm{pH}$ (Figure 5).

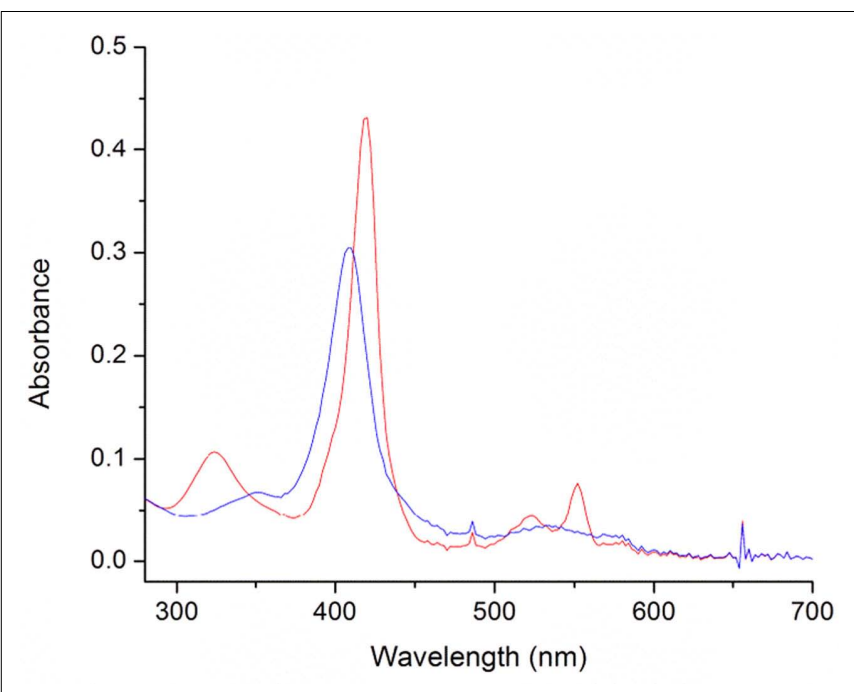

FIGURE 6 | Absorption spectra of MtoA (4 $\mu \mathrm{M})$ in $50 \mathrm{mM} \mathrm{NaCl}$ and $100 \mathrm{mM}$ HEPES buffer $(\mathrm{pH}=7)$ in the oxidized (blue line) and the reduced form (red line).

\section{Fe(II) OXIDATION BY MtoA}

The absorption spectrum of purified, oxidized MtoA exhibited a characteristic peak at $408 \mathrm{~nm}$ ( $\alpha$ peak) with a shoulder at $\sim 352 \mathrm{~nm}$ and a weak absorption band at $\sim 530 \mathrm{~nm}$. After addition of sodium

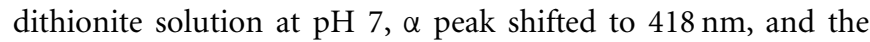
shoulder shifted to $324 \mathrm{~nm}$ to form a distinct peak. In addition, two absorption peaks at $522 \mathrm{~nm}(\beta$ peak) and $552 \mathrm{~nm}(\gamma$ peak) appeared (Figure 6). A similar change was observed in absorption spectra of oxidized and reduced MtrC and OmcA (Wang et al., 2008). The fully reduced MtoA could be rapidly re-oxidized by addition of $1 \mathrm{mM}$ of $\mathrm{Fe}$ (III)-NTA solution (data not shown), which is consistent with previous results that MR-1 MtrA is a bidirectional protein and can mediate electrons in and out of MR1 cells as well as proteoliposomes (Hartshorne et al., 2009; Ross et al., 2011). To investigate the mass balance in $\mathrm{FeCl}_{2}$ oxidation by MtoA, the concentration changes of $\mathrm{Fe}(\mathrm{II})$ ions $(\Delta[\mathrm{Fe}(\mathrm{II})])$ and reduced MtoA ( $[\mathrm{MtoA}]_{\text {red }}$ ) were investigated with $4 \mu \mathrm{M}$ of oxidized MtoA reacted with $\sim 40 \mu \mathrm{M}$ of $\mathrm{FeCl}_{2}$ at $\mathrm{pH} 9$. At the end of the reaction, the ratio of $\Delta[\mathrm{Fe}(\mathrm{II})]$ to $[\mathrm{MtoA}]_{\text {red }}$ was $9.6 \pm 1.5(n=3)$. Changing the initial concentration of MtoA to 2.3 and $3 \mu \mathrm{M}$, respectively, did not significantly change the ratio. Although not all MtoA was reduced by $\mathrm{FeCl}_{2}$ in all experiments, the amount of $\mathrm{Fe}$ (II) ions formed was close to 10 times more than the amount of MtoA reduced. It suggests that, under this condition, 10 hemes in MtoA participated in electron transfer, and no other electron acceptor or donor participated in this reaction.

\section{pH-DEPENDENT Fe(II) OXIDATION BY MtoA}

Absorption spectra of $0.4 \mu \mathrm{M}$ MtoA after reaction with $18 \mu \mathrm{M}$ $\mathrm{FeCl}_{2}$ at $\mathrm{pH} 7,7.5,8,8.5$, and 9, respectively, were compared (Figure 7). The comparison showed that, with the same amount of $\mathrm{FeCl}_{2}$, the absorbance at $552 \mathrm{~nm}$ increased as $\mathrm{pH}$ increased. At $\mathrm{pH}$ 7 , only $1.0 \pm 1.1 \%(n=3)$ of MtoA was reduced by $18 \mu \mathrm{M} \mathrm{FeCl}_{2}$, 

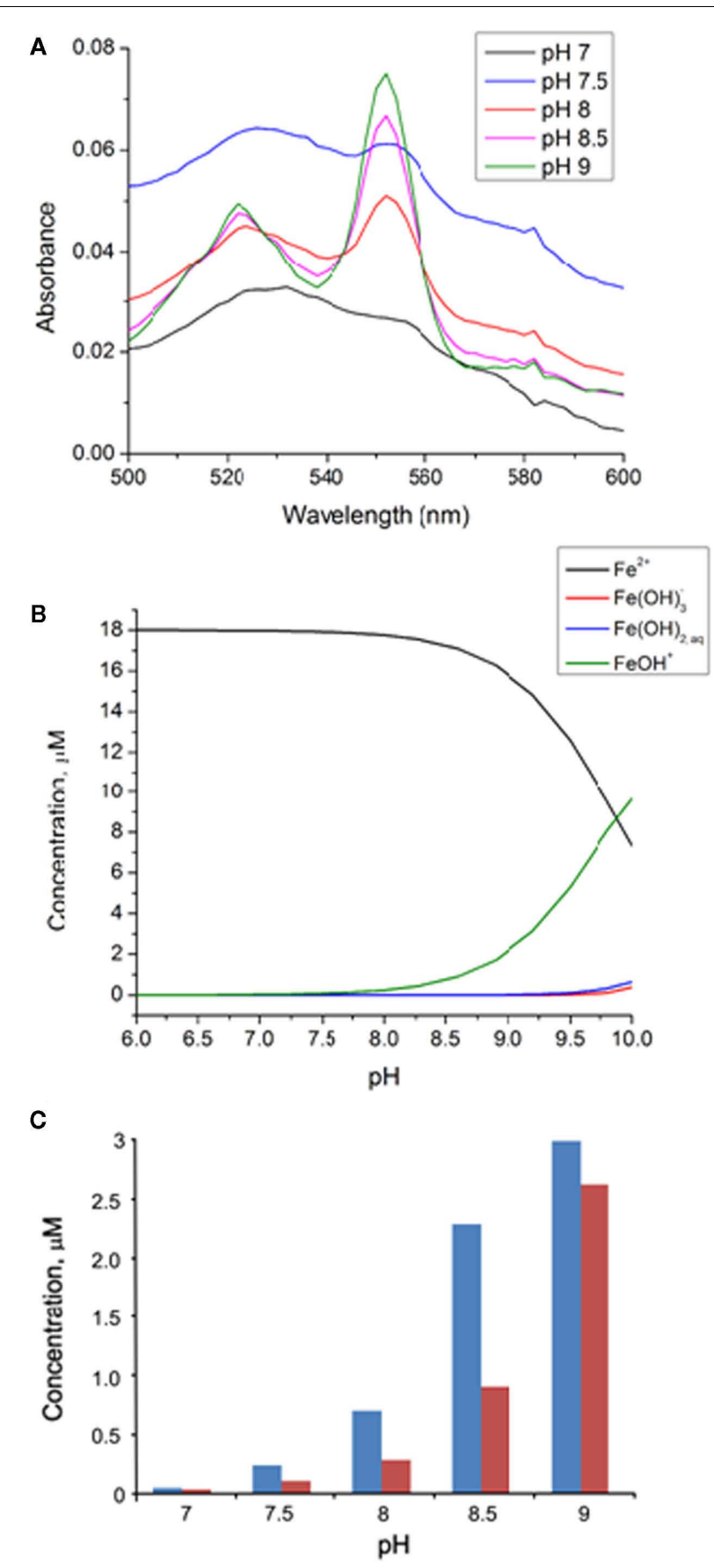

FIGURE 7 | (A) Absorption spectra of MtoA $(0.4 \mu \mathrm{M})$ after the oxidation of $18 \mu \mathrm{M} \mathrm{FeCl}_{2}$ at pH 7 (black), pH 7.5 (blue), $\mathrm{pH} 8$ (red), pH 8.5 (pink), and pH 9 (green). (B) Speciation of $\mathrm{Fe}(\mathrm{II} ; 18 \mu \mathrm{M})$ as a function of $\mathrm{pH}$ in $150 \mathrm{mM}$ $\mathrm{NaCl}$ solution (Allison et al., 1991). (C) Variation of Fe(II; blue columns) oxidized by MtoA at the end of reactions and initial $\left[\mathrm{Fe}(\mathrm{OH})^{+}\right]$(red columns) as a function of $\mathrm{pH}$.

but this percentage increased to $4.9 \pm 0.3 \%(n=3)$ at $\mathrm{pH} 7.5$, $14.7 \pm 3.3 \%(n=3)$ at $\mathrm{pH} 8,48.2 \pm 1.7 \%(n=3)$ at $\mathrm{pH} 8.5$, and $63.0 \pm 9.8 \%(n=3)$ at $\mathrm{pH}$ 9. The maximum fraction of total MtoA reduced by $\mathrm{FeCl}_{2}$ was therefore systematically larger at higher $\mathrm{pH}$.
The same trend was also observed in HEPES buffer at $\mathrm{pH} 7$ and 8 (data not shown). It should be noted that in all of these experiments, MtoA was not totally reduced, even though there was an excess of electron donor, $\mathrm{FeCl}_{2}$. At $\mathrm{pH}$ 9, increasing the concentration of $\mathrm{FeCl}_{2}$ up to $400 \mu \mathrm{M}$ did result in increasingly reduced MtoA. At pH 8, no additional MtoA was reduced as $\left[\mathrm{FeCl}_{2}\right]$ was increased to $840 \mu \mathrm{M}$. Thus, MtoA has the ability to oxidize $\mathrm{FeCl}_{2}$ in the $\mathrm{pH}$ range of $7-9$, but reduction of $\mathrm{MtoA}$ is incomplete even in the presence of excess $\mathrm{FeCl}_{2}$. Similar incomplete redox reaction was observed in the oxidation of reduced MtrF by flavin mononucleotide (FMN). For that system it was proposed that only a subgroup of the 10 hemes in each MtrF molecule participated in FMN reduction based on reduction potential difference estimated between individual hemes and the midpoint potential of FMN/FMNH ${ }_{2}$ (Clarke et al., 2011). However, the mass balance experiment in this study showed that the molar ratio of the consumed $\mathrm{Fe}$ (II) to reduced MtoA was close to $10: 1$, consistent in principle with participation of 10 hemes in each MtoA molecule per $10 \mathrm{Fe}$ (II) oxidized. If only a subgroup of MtoA hemes reacted with $\mathrm{FeCl}_{2}$, this ratio should be $<10$. This suggests that at the end of reaction a subpopulation of MtoA molecules are fully reduced, and incomplete reduction of MtoA is accounted for by a fully oxidized subgroup of MtoA. Hence, in contrast to MtrF, MtoA appears to undergo redox reactions via a cascade whereby once electron transfer into an MtoA molecule begins, it subsequently becomes more energetically favorable to continue reduction of that molecule to completion. This suggests that for any individual MtoA, redox potentials for individual hemes, in CV measurements for example, progressively shift to more oxidizing potentials as reduction proceeds, and vice versa. As $\mathrm{Fe}(\mathrm{II}), \mathrm{Fe}(\mathrm{III})$, and oxidized MtoA concentrations change during the course of reaction, the redox potential difference between ferrous species and MtoA may decrease to zero, at which point the reaction reaches equilibrium. Involvement of all of its 10 hemes during $\mathrm{Fe}$ (II) oxidation implies the ability of MtoA for transferring electrons from extracellular $\mathrm{Fe}$ (II), across the outer membrane, and into the periplasm, which is consistent with the complementation results described above.

\section{LIGAND-DEPENDENT Fe(II) OXIDATION BY MtoA}

Rates of $\mathrm{Fe}$ (II)-complex oxidation by MtoA at $\mathrm{pH} 8$ were investigated using a stopped-flow system. In all experiments, the molar ratio of $\mathrm{Fe}$ (II) to MtoA was 500 . The change of MtoA concentration with time was calculated according to the absorbance change at the $\gamma$ peak. A control experiment was included by mixing MtoA and Tris buffer ( $\mathrm{pH} 8$ ) in which no significant change was observed in the concentration of oxidized MtoA during the time course of study (Figure 8). In all $\mathrm{Fe}(\mathrm{II})$-complex oxidation reactions, the concentration of oxidized MtoA changed in a similar way. It initially decreased very fast, and then the rate of change decreased to reach redox equilibrium. All reactions reached equilibrium within $2 \mathrm{~min}$. The fraction of MtoA reduced by Fe(II)-complexes at the end of each reaction was in the order $\mathrm{Fe}(\mathrm{II}) \mathrm{Cl}_{2}>\mathrm{Fe}$ (II)citrate $>\mathrm{Fe}(\mathrm{II})-\mathrm{NTA}>\mathrm{Fe}(\mathrm{II})$-EDTA (Figure 8).

The stopped-flow kinetic data were fitted to a second-order rate model using Eq. 3 . The rate constant, $k$, was derived from the slope of fitted curves in the fast stage, and the equilibrium constant, 
$K$, was determined from the equilibrium stage (Table 1). Rate and equilibrium constants were significantly affected by ligand type. The order for the oxidation rates are similar to the final oxidation fraction, which was $\mathrm{Fe}(\mathrm{II}) \mathrm{Cl}_{2}>\mathrm{Fe}(\mathrm{II})-$ citrate $>\mathrm{Fe}(\mathrm{II})-$ NTA $>$ Fe(II)-EDTA. These experiments showed that the type of ligand significantly affected the oxidation kinetics of $\mathrm{Fe}$ (II)complexes by MtoA. Compared to the reduction rates of the analogous $\mathrm{Fe}(\mathrm{III})$-complexes by $\mathrm{MtrC}$ and $\mathrm{OmcA}$, which ranged from $0.872 \mu \mathrm{M}^{-1} \mathrm{~s}^{-1}$ for the reaction between MtrC and Fe(III)EDTA to $0.012 \mu \mathrm{M}^{-1} \mathrm{~s}^{-1}$ for the reaction between OmcA and the Fe(III)-citrate (Wang et al., 2008), the oxidation rates of $\mathrm{Fe}(\mathrm{II})$-complexes by MtoA were two orders of magnitude slower. Moreover, in the $\mathrm{Fe}$ (III)-complex reduction reactions by $\mathrm{MtrC}$ and OmcA, there was enough free energy driving the redox reaction to consume all heme groups. However, consistent with the discussion above regarding reaction incompleteness, the free energy in the present system was not sufficient for all MtoA to participate in the redox reaction.

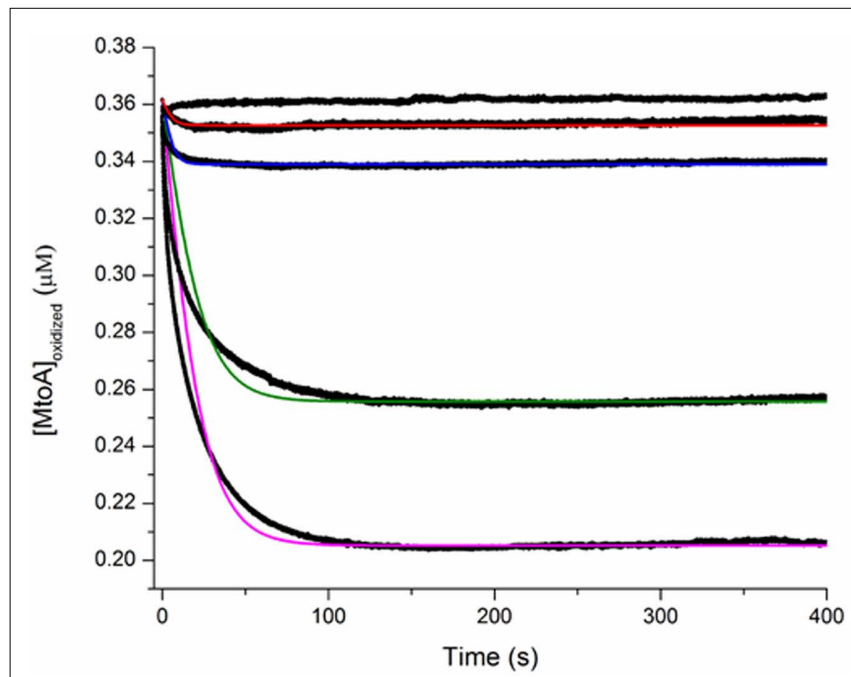

FIGURE 8 | Stopped-flow spectrophotometry results of the oxidation of $0.2 \mathrm{mM} \mathrm{Fe}$ (II)-complexes by $0.4 \mu \mathrm{M}$ MtoA at pH 8 [black dots; from the top to the bottom is MtoA solution without Fe(II)-complexes (control), $\mathrm{Fe}$ (II)-EDTA, $\mathrm{Fe}(\mathrm{II})-\mathrm{NTA}, \mathrm{Fe}$ (II)-citrate, and $\mathrm{Fe}(\mathrm{II}) \mathrm{Cl}_{2}$ ]. The fitted curves for the kinetic data of MtoA reduction with $\mathrm{Fe}(\mathrm{II}) \mathrm{Cl}_{2}$ (purple), $\mathrm{Fe}(\mathrm{II})$-citrate (green), Fe(II)-NTA (blue), and Fe(II)-EDTA (red).

\section{DISCUSSION}

The increased oxidation of $\mathrm{Fe}(\mathrm{II}) \mathrm{Cl}_{2}$ by $\mathrm{MtoA}$ from $\mathrm{pH} 7$ to $\mathrm{pH} 9$ may be attributed mainly to the expected increased concentration of hydroxylated species of $\mathrm{Fe}(\mathrm{II})$, such as $\mathrm{Fe}(\mathrm{OH})^{+}$and $\mathrm{Fe}(\mathrm{OH})_{2}$. Equilibrium speciation calculations based on Minteqa2 thermodynamic database (Allison et al., 1991) as plotted in Figure 7B show the speciation of $\mathrm{Fe}(\mathrm{II} ; 18 \mu \mathrm{M})$ in $150 \mathrm{mM} \mathrm{NaCl}$ solution as a function of $\mathrm{pH}$. Hexaquo ferrous ion is the dominant species in the $\mathrm{pH}$ range used in this study, but the amount of $\mathrm{Fe}(\mathrm{OH})^{+}$increases with increasing $\mathrm{pH}$, especially when $\mathrm{pH}$ is greater than 7.5 . Both thermodynamic calculations and experimental data indicate that hydroxylated species of $\mathrm{Fe}(\mathrm{II})$ have higher reactivity relative to hexaquo Fe(II) (e.g., Wehrli, 1990; Sedlak and Chan, 1997). $\mathrm{OH}^{-}$ ligands in the inner coordination shell of $\mathrm{Fe}(\mathrm{II})$ increase its reducing potential and increase its oxidation rate, and therefore could increase reaction to product $\mathrm{Fe}(\mathrm{III})$ phases. The concentration change of $\mathrm{Fe}(\mathrm{II})$, including hexaquo $\mathrm{Fe}(\mathrm{II})$ and $\mathrm{Fe}(\mathrm{OH})^{+}$, at the end of $\mathrm{pH}$-dependent experiments was compared to the initial $\mathrm{Fe}(\mathrm{OH})^{+}$concentration (Figure 7C). It shows that the amount of $\mathrm{Fe}(\mathrm{II})$ oxidized by MtoA appears to correlate positively with the initial concentration of $\mathrm{Fe}(\mathrm{OH})^{+}$from $\mathrm{pH} 7$ to $\mathrm{pH}$ 9. Notably, at $\mathrm{pH} 9$, the initial concentration of $\mathrm{Fe}(\mathrm{OH})^{+}$is expected to be significantly higher than that at $\mathrm{pH} 8.5$, but the amount of $\mathrm{Fe}$ (II) oxidized by MtoA only increases slightly. This discrepancy is caused, at least in part, by the fact that the average redox potential of MtoA decreases as $\mathrm{pH}$ increases. This decrease is particularly accelerated from $\mathrm{pH} 8.2$ to $\mathrm{pH}$ 9.2. The decrease of the redox potential of MtoA from $\mathrm{pH} 8.2$ to $\mathrm{pH} 9.2$ could negatively offset the increase of $\mathrm{Fe}(\mathrm{OH})^{+}$concentration in the same $\mathrm{pH}$ range, which may have the net result of only a slight increase of the $\mathrm{Fe}(\mathrm{II})$ oxidized by MtoA at $\mathrm{pH}$ 9. These results imply that change of $\mathrm{pH}$ in the environments may also have significant influence on $\mathrm{Fe}$ (II) speciation, which in turn will strongly affect microorganism-mediated $\mathrm{Fe}(\mathrm{II})$ oxidation in their natural settings.

Ligand types impact both reaction rates and equilibrium constants of redox reactions between $\mathrm{Fe}$ (II)-complexes and MtoA. The equilibrium speciation calculations showed that the dominant $\mathrm{Fe}$ (II) species in the four ligand systems is hexaquo $\mathrm{Fe}$ (II), $\mathrm{Fe}(\mathrm{II})-$ citrate $^{-}, \mathrm{FeOH}_{-} \mathrm{NTA}^{-}$, and $\mathrm{Fe}-\mathrm{EDTA}^{-}$, respectively, at a ferrous ion-to-ligand ratio of 1:10. The equilibrium constant for the half electron transfer reactions between $\mathrm{Fe}(\mathrm{II})$-ligand and $\mathrm{Fe}$ (III)-ligand (Table 2) was calculated using the thermodynamic cycle that involves ligand detachment from Fe(II)-ligand complex,

Table 1 | Kinetic parameters for Fe-complexes oxidation by MtoA at pH 8.

\begin{tabular}{|c|c|c|c|c|}
\hline Complex & Rate constants $\left(k, \mu \mathrm{m}^{-1} \mathrm{~s}^{-1}\right)$ & Equilibrium constant $(K)$ & $\log K_{\mathrm{ob}}{ }^{\mathrm{a}}$ & $\log K_{\text {calc }}{ }^{b}$ \\
\hline Fe-citrate & $(4.1 \pm 0.8) \times 10^{-3}$ & $(2.4 \pm 0.4) \times 10^{-3}$ & -2.66 & $-5.46^{d}$ \\
\hline Fe-EDTA & $(1.0 \pm 0.3) \times 10^{-3}$ & $(2.1 \pm 1.5) \times 10^{-5}$ & -4.959 & -1.35 \\
\hline
\end{tabular}

${ }^{a} L o g K_{o b}$ was calculated from the $K$ values estimated from the fitted curve.

${ }^{b}$ Log $K_{\text {calc }}$ was calculated from theoretical Log K using experimental condition.

${ }^{c}$ Calculated assuming in equilibrium with ferrihydrite.

${ }^{d}$ Calculated by using thermodynamic data of Fe(III)citrate in Minteqa database. 
Table 2 | Relevant speciation reactions for calculating reaction-free energy at $25^{\circ} \mathrm{C}$.

\begin{tabular}{|c|c|c|}
\hline Reaction & $\log K(I=0)$ & Reference \\
\hline $\mathrm{Fe}(\mathrm{III})+\mathrm{e}^{-} \rightarrow \mathrm{Fe}(\mathrm{II})$ & 13.00 & $\begin{array}{l}\text { Martell and Smith } \\
\text { (1995) }\end{array}$ \\
\hline $\mathrm{Fe}(\mathrm{III})-3 \mathrm{H}^{+}+3 \mathrm{H}_{2} \mathrm{O}=\mathrm{Fe}(\mathrm{OH})_{3}$ & -3.96 & $\begin{array}{l}\text { Cornell and Schw- } \\
\text { ertmann (2003) }\end{array}$ \\
\hline $\begin{array}{l}\mathrm{Fe}(\mathrm{II})+\text { citrate }^{3-} \rightarrow \mathrm{Fe}(\mathrm{II})- \\
\text { citrate }^{-}\end{array}$ & 5.89 & $\begin{array}{l}\text { Martell and Smith } \\
\text { (1995) }\end{array}$ \\
\hline $\mathrm{Fe}(\mathrm{III})+$ citrate $^{3-} \rightarrow \mathrm{Fe}(\mathrm{III})$-citrate & 13.43 & $\begin{array}{l}\text { Allison et al. (1991), } \\
\text { Timberlake (1964) }\end{array}$ \\
\hline $\begin{array}{l}\mathrm{Fe}(\mathrm{III}) \mathrm{OH}-\mathrm{NTA}^{-}+\mathrm{e}^{-} \rightarrow \\
\mathrm{Fe}(\mathrm{II}) \mathrm{OH}-\mathrm{NTA}^{2-}\end{array}$ & 0.82 & Wang et al. (2008) \\
\hline $\begin{array}{l}\mathrm{Fe}(\mathrm{III})-\mathrm{EDTA}^{-}+\mathrm{e}^{-} \rightarrow \mathrm{Fe}(\mathrm{II})- \\
\mathrm{EDTA}^{2-}\end{array}$ & 1.35 & Wang et al. (2008) \\
\hline
\end{tabular}

I, ionic strength.

$\mathrm{Fe}(\mathrm{II})$ oxidation to $\mathrm{Fe}(\mathrm{III})$ and $\mathrm{Fe}(\mathrm{III})-$ ligand complexation:

$$
\begin{array}{ccc}
\mathrm{Fe}(\mathrm{II}) \text {-ligand }-\mathrm{e}^{-} & \rightarrow & \mathrm{Fe}(\mathrm{III}) \text {-ligand } \\
\downarrow & & \uparrow \\
- \text { ligand } & & + \text { ligand } \\
\downarrow & & \uparrow \\
\mathrm{Fe}(\mathrm{II})-\mathrm{e}^{-} & \rightarrow & \mathrm{Fe}(\mathrm{III})
\end{array}
$$

Reaction equilibrium constants in this electron transfer pathway are provided in Table 2. For the case of $\mathrm{FeCl}_{2}$ at $\mathrm{pH} 8$, it is reasonable to assume that the concentration of produced $\mathrm{Fe}$ (III) was controlled by the solubility of $\mathrm{FH}\left[\mathrm{Fe}(\mathrm{OH})_{3}\right]$ because organic ligand was not provided. The equilibrium constant for electron transfer from $\mathrm{Fe}(\mathrm{II})$ to $\mathrm{FH}(\log K=7.04$; Table 1$)$ was then calculated by combining the redox reaction of $\mathrm{Fe}(\mathrm{II}) / \mathrm{Fe}(\mathrm{III})$ and the formation reaction of FH (Table 2). The trend of calculated $\log K$ is consistent with that of the $\log K$ values fitted from the experimental data except for the Fe-citrate case (Table 1 ). The exception is likely because of incomplete understanding of the speciation in the $\mathrm{Fe}(\mathrm{III})$-citrate system; two $\mathrm{Fe}(\mathrm{III})$-citrate speciation models were assembled previously based on literature data (Liu et al., 2001) that involve completely different $\mathrm{Fe}$ (III) speciation. In this study, we used the speciation model 1 in Liu et al. (2001), which is also used in the Minteqa2 database (Allison et al., 1991). In this model, the $\log K$ for the equation:

$\mathrm{Fe}(\mathrm{III})+$ citrate $^{3-} \rightarrow \mathrm{Fe}(\mathrm{III})-$ citrate

is 13.43 Speciation calculations in our $\mathrm{Fe}(\mathrm{III})$-citrate system using Eq. 5, however, suggested that $\mathrm{Fe}(\mathrm{III})$-citrate is not a stable species if $\mathrm{Fe}(\mathrm{III})$ is allowed to precipitate as $\mathrm{FH}$. The alternative $\mathrm{Fe}(\mathrm{III})-\mathrm{citrate}$ speciation model produced the same result. If the $\mathrm{FH}$ is used as the end product, then the overall reaction constant $(\log K)$ from $\mathrm{Fe}(\mathrm{II})-$ citrate to $\mathrm{FH}$ at $\mathrm{pH} 8$ is 1.15 . With this value, the trend of the calculated equilibrium reaction constants was consistent with the value estimated from the experimental data.

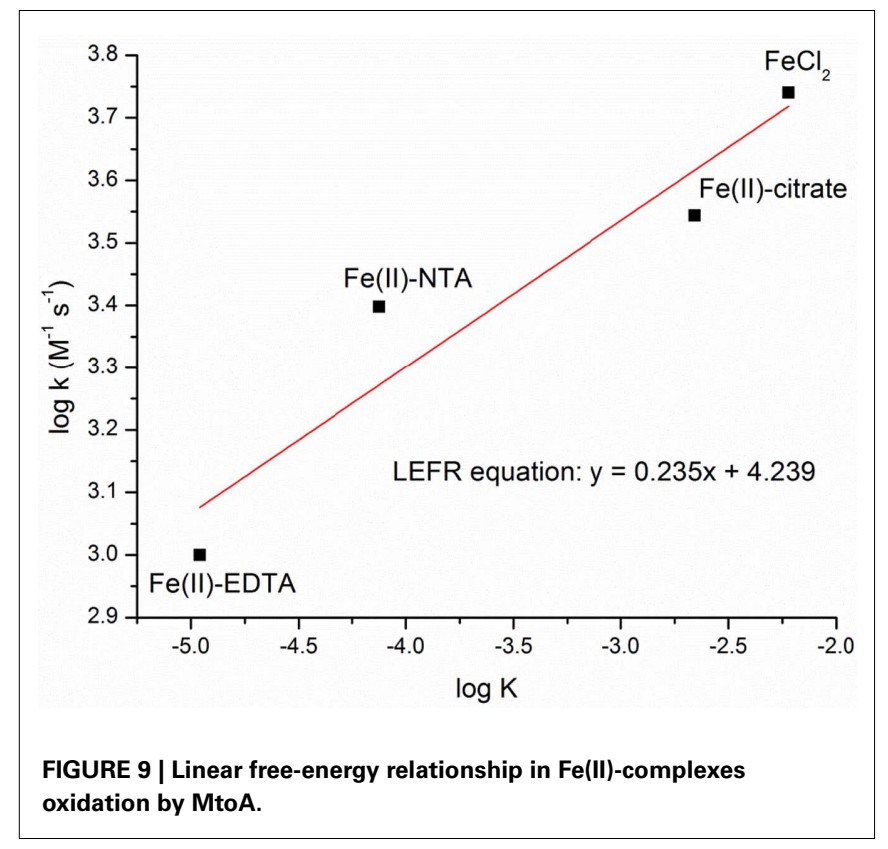

The estimated reaction rate constants $(k)$ and equilibrium constants $(K)$ were positively correlated, establishing a linear freeenergy relationship for this system (Figure 9). This result implies that it is the reaction-free energy that mainly determined the observed initial reaction rates when it was far away from equilibrium. It is interesting to note that the rate constant order of $\mathrm{Fe}$ (II)-complex oxidation, $\mathrm{Fe}$-citrate $>\mathrm{Fe}-\mathrm{NTA}>\mathrm{Fe}-\mathrm{EDTA}$, is the inverse order observed in the reduction of $\mathrm{Fe}$ (III) complexes by $\mathrm{MtrC}$ and $\mathrm{OmcA}$, where the $\mathrm{Fe}$ (III)-ligand reduction rate was $\mathrm{Fe}$ (III)-EDTA $>\mathrm{Fe}$ (III)-NTA $>\mathrm{Fe}$ (III)-citrate (Wang et al., 2008). This is expected from the trend of the activation-free energies for the redox reactions between Fe-complex and proteins (Wang et al., 2008). It is also expected from the relationship of $K=k_{\mathrm{f}} / k_{\mathrm{b}}$, where $k_{\mathrm{f}}$ and $k_{\mathrm{b}}$ are the forward [Fe(II) oxidation] and backward [Fe(III) reduction] reaction rate constants, respectively, and $K$ is the equilibrium constant. Using the estimated $K$ and $k$, which is $k_{\mathrm{f}}$ here (Table $\mathbf{1}$ ), the calculated $k_{\mathrm{b}}=k_{\mathrm{f}} / K$, is on the order of $\mathrm{Fe}$-citrate $<\mathrm{Fe}-\mathrm{NTA}<\mathrm{Fe}-\mathrm{EDTA}$, which is consistent with those observed by Wang et al. (2008). These two studies therefore demonstrate the same effect of ligand complexation on the reaction rates for both reduction and oxidation reactions, indicating that complexing ligands will have a significant impact on the reaction rates of microorganism-mediated $\mathrm{Fe}(\mathrm{II})$ oxidation in the environments.

In MR-1, MtrAB form a tight protein complex on the OM where MtrB is proposed to serve as a sheath for embedding MtrA and MtrA mediates electron conductance across the OM, while CymA is located in the inner membrane where it recycles quinol back to quinone during extracellular Fe(III) oxide reduction (Hartshorne et al., 2009). In this study, we showed that MtoA was a functional $\mathrm{Fe}(\mathrm{II})$-oxidizing protein with broad redox potential that was more positive than that of MR-1 MtrA, indicating that, like MR-1 MtrA, MtoA is also capable of mediating electron conductance across the $\mathrm{OM}$, but with the direction opposite to that of MR-1 MtrA during 
metal-reducing conditions. In addition, ES-1 $m t o A B-c y m A$ is, to the best of our knowledge, the first example that the genes encoding MtrAB and CymA homologs are clustered together, which suggests that they may belong to the same operon and that their protein products may work together for mediating electron transfer reactions. Based on previous observations and the results from this study, we propose that, similar to MtrAB and CymA in MR-1 cells, MtoAB and CymA $A_{E S-1}$ are also located in the OM and inner membrane, respectively, where MtoA is embedded inside MtoB. However, the direction of MtoAB/CymA $\mathrm{ES}_{-1}$-mediated electron transfer during $\mathrm{Fe}$ (II) oxidation (i.e., outside-in) by ES-1 is opposite to that of MtrABC/CymA-mediated reactions during $\mathrm{Fe}$ (III) reduction (i.e., inside-out) by MR-1. We propose that through its heme group(s) exposed to the extracellular environment, MtoA oxidizes $\mathrm{Fe}(\mathrm{II})$ directly and then transfers the released electrons across the OM to periplasmic proteins that have yet to be identified, which in turn relay the electrons to CymA $A_{E S-1}$. CymA $A_{E S-1}$ uses the received electrons to reduce quinone to quinol in the inner membrane (Figure 10). Quinol then shuttles the electrons to the redox proteins in the inner membrane for reducing $\mathrm{O}_{2}$ and/or $\mathrm{NAD}^{+}$.

PioABC homologs are also found in the $\mathrm{Fe}(\mathrm{II})$-oxidizing bacterium Gallionella capsiferriformans (Bonnefoy and Holmes, 2011), indicating the broad involvements of MtoAB/PioAB homologs in microbial $\mathrm{Fe}$ (II) oxidation. It should be noted that a group of proteins that show no homologous to MtoAB/CymAES-1 have recently been proposed to be involved in $\mathrm{Fe}$ (II) oxidation by the bacterium Mariprofundus ferrooxydans PV-1 and homologs of these proteins are also present in ES-1 (Singer et al., 2011). These results emphasize the uncertainty that remains regarding the electron transfer pathway(s) utilized by ES-1 for Fe(II) oxidation and the need for additional research.

In summary, an $m t o A B-c y m A$ gene cluster is found in the genome of the $\mathrm{Fe}(\mathrm{II})$-oxidizing bacterium $S$. lithotrophicus ES-1. Protein purification and characterization results confirm that MtoA is a decaheme $c$-type cytochrome and oxidizes soluble $\mathrm{Fe}$ (II). MtoA-mediated $\mathrm{Fe}$ (II) oxidation is $\mathrm{pH}$ - and

\section{REFERENCES}

Allison, J. D., Brown, D. S., and Novo-Gradac, K. J. (1991). MINITEQ2//PRODEFA2, A Geochemical Assessment Model for Environmental Systems, 3 Edn. Washington, DC: US Environmental Protection Agency.

Appia-Ayme, C., Guiliani, N., Ratouchniak, J., and Bonnefoy, V. (1999). Characterization of an operon encoding two $c$-type cytochromes, an aa(3)-type cytochrome oxidase, and rusticyanin in Thiobacillus ferrooxidans ATCC 33020. Appl. Environ. Microbiol. 65, 4781-4787.

Asher, W. B., and Bren, K. L. (2010). A heme fusion tag for protein affinity purification and quantification. Protein Sci. 19, 1830-1839.

Bonnefoy, V., and Holmes, D. S. (2011). Genomic insights into microbial iron oxidation and iron uptake strategies in extremely acidic environments. Environ. Microbiol. doi:10.1111/j.1462-2920.2011.02626

Castelle, C., Guiral, M., Malarte, G., Ledgham, F., Leroy, G., Brugna, M., and Giudici-Orticoni, M. T. (2008). A new iron-oxidizing $/ \mathrm{O}_{2}$ reducing supercomplex spanning both inner and outer membranes, isolated from the extreme acidophile Acidithiobacillus ferrooxidans. J. Biol. Chem. 283, 25803-25811.

Clarke, T. A., Edwards, M. J., Gates, A. J., Hall, A., White, G. F., Bradley, J., Reardon, C. L., Shi, L., Beliaev, A. S., Marshall, M. J., Wang, Z. M., Watmough, N. J., Fredrickson, J. K., Zachara, J. M., Butt, J. N., and Richardson, D. J. (2011). Structure of a bacterial cell

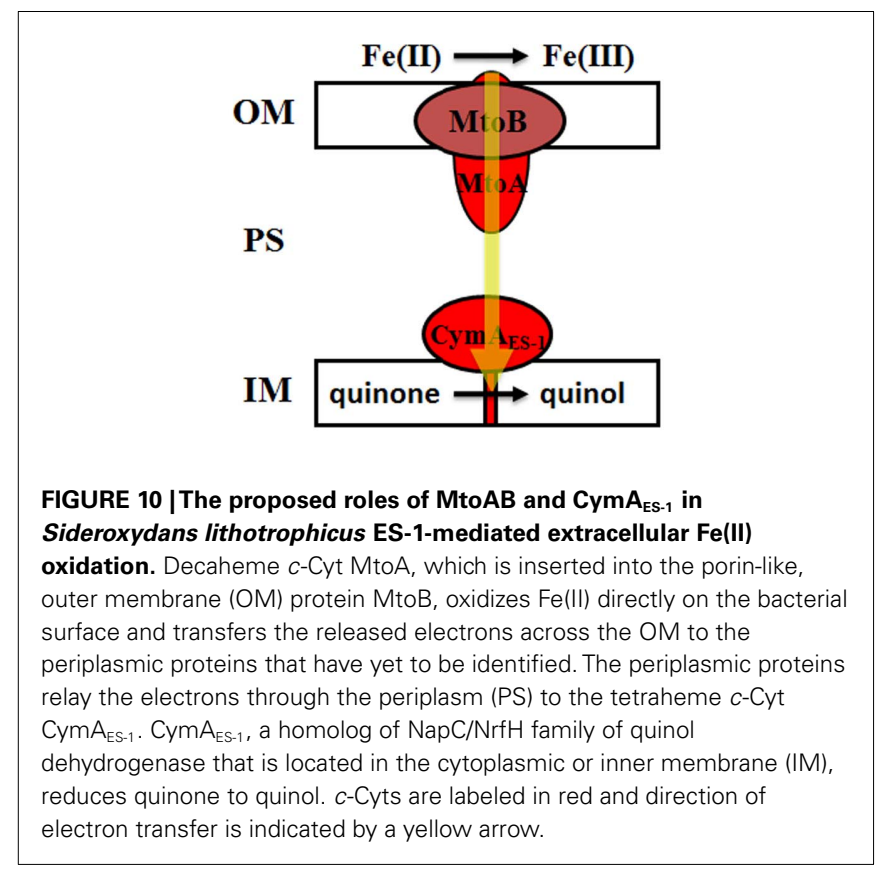

$\mathrm{Fe}$ (II)-complexing ligand-dependent. It is proposed that, together, MtoAB and CymA $A_{E S-1}$ form a pathway for electron conductance from extracellular $\mathrm{Fe}$ (II) to the quinone pool in the bacterial inner membrane.

\section{ACKNOWLEDGMENTS}

This research was supported by the Subsurface Biogeochemical Research program (SBR)/Office of Biological and Environmental Research (BER), U.S. Department of Energy (DOE), and is a contribution of the Pacific Northwest National Laboratory (PNNL) Scientific Focus Area. A portion of the research was performed using EMSL, a national scientific user facility sponsored by DOEBER and located at PNNL. PNNL is operated for DOE by Battelle under contract DE-AC05-76RLO 1830.

surface decaheme electron conduit. Proc. Natl. Acad. Sci. U.S.A. 108, 9384-9389.

Cornell, R. M., and Schwertmann, U. (2003). The Iron Oxides: Structure, Properties, Reactions, Occurrences and Uses. Weinheim: Wiley$\mathrm{VCH}$.

Coursolle, D., and Gralnick, J. A. (2010). Modularity of the Mtr respiratory pathway of Shewanella oneidensis strain MR-1. Mol. Microbiol. 77, 995-1008.

Croal, L. R., Jiao, Y., and Newman, D. K. (2007). The fox operon from Rhodobacter strain SW2 promotes phototrophic Fe(II) oxidation in Rhodobacter capsulatus SB1003. J. Bacteriol. 189, 1774-1782.

Emerson, D., Fleming, E. J., and Mcbeth, J. M. (2010). Iron-oxidizing bacteria: an environmental and genomic perspective. Annu. Rev. Microbiol. 64, 561-583.

Emerson, D., and Moyer, C. (1997). Isolation and characterization of novel iron-oxidizing bacteria that grow at circumneutral pH. Appl. Environ. Microbiol. 63, 4784-4792.

Emerson, D., Rentz, J. A., Lilburn, T. G., Davis, R. E., Aldrich, H., Chan, C., and Moyer, C. L. (2007). A novel lineage of proteobacteria involved in formation of marine Fe-oxidizing microbial mat communities. PLoS ONE 2, e667. doi:10.1371/journal.pone.0000667

Eng, J. K., McCormack, A. L., and Yates Iii, J. R. (1994). An approach to correlate tandem mass spectral data of peptides with amino acid sequences in a protein database. J. Am. Soc. Mass Spectrom. 5, 976-989. 
Fredrickson, J. K., Romine, M. F., Beliaev, A. S., Auchtung, J. M., Driscoll, M. E., Gardner, T. S., Nealson, K. H., Osterman, A. L., Pinchuk, G., Reed, J. L., Rodionov, D. A., Rodrigues, J. L., Saffarini, D. A., Serres, M. H., Spormann, A. M., Zhulin, I. B., and Tiedje, J. M. (2008). Towards environmental systems biology of Shewanella. Nat. Rev. Microbiol. 6, 592-603.

Gralnick, J. A., Vali, H., Lies, D. P., and Newman, D. K. (2006). Extracellular respiration of dimethyl sulfoxide by Shewanella oneidensis strain MR1. Proc. Natl. Acad. Sci. U.S.A. 103, 4669-4674.

Hartshorne, R. S., Reardon, C. L., Ross, D., Nuester, J., Clarke, T. A., Gates, A. J., Mills, P. C., Fredrickson, J. K., Zachara, J. M., Shi, L., Beliaev, A. S., Marshall, M. J., Tien, M., Brantley, S., Butt, J. N., and Richardson, D. J. (2009). Characterization of an electron conduit between bacteria and the extracellular environment. Proc. Natl. Acad. Sci. U.S.A. 106, 22169-22174.

Jiao, Y., and Newman, D. K. (2007). The pio operon is essential for phototrophic $\mathrm{Fe}(\mathrm{II})$ oxidation in Rhodopseudomonas palustris TIE-1. J. Bacteriol. 189, 1765-1773.

Liu, C. G., Zachara, J. M., Gorby, Y. A., Szecsody, J. E., and Brown, C. F. (2001). Microbial reduction of $\mathrm{Fe}(\mathrm{III})$ and sorption/precipitation of $\mathrm{Fe}(\mathrm{II})$ on Shewanella putrefaciens strain CN32. Environ. Sci. Technol. 35, 1385-1393.

Livesay, E. A., Tang, K., Taylor, B. K., Buschbach, M. A., Hopkins, D. F., Lamarche, B. L., Zhao, R., Shen, Y., Orton, D. J., Moore, R. J., Kelly, R. T., Udseth, H. R., and Smith, R. D. (2007). Fully automated four-column capillary LC-MS system for maximizing throughput in proteomic analyses. Anal. Chem. 80, 294-302.

Lower, B. H., Yongsunthon, R., Shi, L., Wildling, L., Gruber, H. J., Wigginton, N. S., Reardon, C. L., Pinchuk, G. E., Droubay, T. C., Boily, J. F., and Lower, S. K. (2009). Antibody recognition force microscopy shows that outer membrane cytochromes OmcA and MtrC are expressed on the exterior surface of Shewanella oneidensis MR-1. Appl. Environ. Microbiol. 75, 2931-2935.
Martell, R. E., and Smith, R. M. (1995). Critical Stability Constants of Metal Complexes Database. Gaithersburg, MD: NIST Standard Reference Database.

Reardon, C. L., Dohnalkova, A. C., Nachimuthu, P., Kennedy, D. W., Saffarini, D. A., Arey, B. W., Shi, L., Wang, Z., Moore, D., Mclean, J. S., Moyles, D., Marshall, M. J., Zachara, J. M., Fredrickson, J. K., and Beliaev, A. S. (2010). Role of outermembrane cytochromes $\mathrm{MtrC}$ and OmcA in the biomineralization of ferrihydrite by Shewanella oneidensis MR-1. Geobiology 8, 56-68.

Richardson, D. J. (2000). Bacterial respiration: a flexible process for a changing environment. Microbiology 146(Pt 3), 551-571.

Ross, D. E., Flynn, J. M., Baron, D. B., Gralnick, J. A., and Bond, D. R. (2011). Towards electrosynthesis in Shewanella: energetics of reversing the mtr pathway for reductive metabolism. PLoS ONE 6, e16649. doi:10.1371/journal.pone.0016649

Ross, D. E., Ruebush, S. S., Brantley, S. L., Hartshorne, R. S., Clarke, T. A., Richardson, D. J., and Tien, M. (2007). Characterization of proteinprotein interactions involved in iron reduction by Shewanella oneidensis MR-1. Appl. Environ. Microbiol. 73, 5797-5808.

Sedlak, D. L., and Chan, P. G. (1997). Reduction of hexavalent chromium by ferrous iron. Geochim. Cosmochim. Acta 61, 2185-2192.

Shi, L., Belchik, S. M., Wang, Z., Kennedy, D. W., Dohnalkova, A. C., Marshall, M. J., Zachara, J. M., and Fredrickson, J. K. (2011). Identification and characterization of UndAHRCR-6, an outer membrane endecaheme $c$-type cytochrome of Shewanella sp. strain HRCR6. Appl. Environ. Microbiol. 77, 5521-5523.

Shi, L., Deng, S., Marshall, M. J., Wang, Z., Kennedy, D. W., Dohnalkova, A. C., Mottaz, H. M., Hill, E. A., Gorby, Y. A., Beliaev, A. S., Richardson, D. J., Zachara, J. M., and Fredrickson, J. K. (2008). Direct involvement of type II secretion system in extracellular translocation of Shewanella oneidensis outer membrane cytochromes MtrC and OmcA. J. Bacteriol. 190, 5512-5516.
Shi, L., Lin, J. T., Markillie, L. M., Squier T. C., and Hooker, B. S. (2005). Overexpression of multi-heme Ctype cytochromes. BioTechniques 38 , 297-299.

Shi, L., Potts, M., and Kennelly, P. J. (1998). The serine, threonine, and/or tyrosine-specific protein kinases and protein phosphatases of prokaryotic organisms: a family portrait. FEMS Microbiol. Rev. 22, 229-253.

Shi, L., Richardson, D. J., Wang, Z., Kerisit, S. N., Rosso, K. M. Zachara, J. M., and Fredrickson, J. K. (2009). The roles of outer membrane cytochromes of Shewanella and Geobacter in extracellular electron transfer. Environ. Microbiol. Rep. 1, 220-227.

Shi, L., Squier, T. C., Zachara, J. M., and Fredrickson, J. K. (2007). Respiration of metal (hydr)oxides by Shewanella and Geobacter: a key role for multihaem c-type cytochromes. Mol. Microbiol. 65, 12-20.

Shi, L., and Zhang, W. (2004). Comparative analysis of eukaryotic-type protein phosphatases in two streptomycete genomes. Microbiology 150, 2247-2256.

Singer, E., Emerson, D., Webb, E. A. Barco, R. A., Kuenen, J. G., Nelson, W. C., Chan, C. S., Comolli, L. R., Ferriera, S., Johnson, J., Heidelberg, J. F., and Edwards, K. J. (2011). Mariprofundus ferrooxydans PV-1 the first genome of a marine $\mathrm{Fe}(\mathrm{II})$ oxidizing Zetaproteobacterium. PLoS ONE 6, e25386. doi:10.1371/journal.pone. 0025386

Stookey, L. (1970). Ferrozine-a new spectrophotometric reagent for iron. Anal. Chem. 42, 779-781.

Thomas, P. E., Ryan, D., and Levin, W. (1976). An improved staining procedure for the detection of the peroxidase activity of cytochrome P450 on sodium dodecyl sulfate polyacrylamide gels. Anal. Biochem. 75 168-176.

Timberlake, C. F. (1964). Iron-malate + iron-citrate complexes. J. Chem. Soc. 5078-5085.

Wang, Z. M., Liu, C. X., Wang, X. L., Marshall, M. J., Zachara, J. M., Rosso, K. M., Dupuis, M., Fredrickson, J. K., Heald, S., and Shi, L. (2008). Kinetics of reduction of $\mathrm{Fe}$ (III) complexes by outer membrane cytochromes MtrC and OmcA of Shewanella oneidensis
MR-1. Appl. Environ. Microbiol. 74, 6746-6755.

Wehrli, B. (1990). "Redox reactions of metal ions at mineral surfaces," in Aquatic Chemcial Kinetics: Reaction Rates of Processes in Natural Waters, ed. W. Stumm (Wiley), 311-336.

Yang, F., Bogdanov, B., Strittmatter, E. F., Vilkov, A. N., Gritsenko, M., Shi, L. Elias, D. A., Ni, S., Romine, M., PašaTolic, L., Lipton, M. S., and Smith, R D. (2005). Characterization of purified $c$-type heme-containing peptides and identification of $c$-type heme-attachment sites in Shewanella oneidensis cytochromes using mass spectrometry. J. Proteome Res. 4, 846-854.

Yarzabal, A., Brasseur, G., Ratouchniak, J., Lund, K., Lemesle-Meunier, D. DeMoss, J. A., and Bonnefoy, V. (2002). The high-molecular-weight cytochrome $c$ Cyc2 of Acidithiobacillus ferrooxidans is an outer membrane protein. J. Bacteriol. 184, 313-317.

Conflict of Interest Statement: The authors declare that the research was conducted in the absence of any commercial or financial relationships that could be construed as a potential conflict of interest.

Received: 22 October 2011; accepted: 23 January 2012; published online: $08 \mathrm{Feb}$ ruary 2012.

Citation: Liu J, Wang Z, Belchik SM, Edwards MJ, Liu C, Kennedy DW, Merkley ED, Lipton MS, Butt JN, Richardson DJ, Zachara JM, Fredrickson JK, Rosso KM and Shi L (2012) Identification and characterization of MtoA: a decaheme c-type cytochrome of the neutrophilic $\mathrm{Fe}$ (II)-oxidizing bacterium Sideroxydans lithotrophicus ES-1. Front. Microbio. 3:37. doi 10.3389/fmicb.2012.00037

This article was submitted to Frontiers in Microbiological Chemistry, a specialty of Frontiers in Microbiology.

Copyright () 2012 Liu, Wang, Belchik, Edwards, Liu, Kennedy, Merkley, Lipton, Butt, Richardson, Zachara, Fredrickson, Rosso and Shi. This is an open-access article distributed under the terms of the Creative Commons Attribution Non Commercial License, which permits noncommercial use, distribution, and reproduction in other forums, provided the original authors and source are credited. 